\title{
Community Empowerment Model through Cooperative for the Villages Most Severely Affected By Eruption of Merapi
}

\author{
Masrukin, Ahmad Sabiq, Toto Sugito, Bambang Suswanto, and Adhi Iman Sulaiman
}

\begin{abstract}
This study was intended to set up community empowerment model for the villages most severely affected after the eruption of Mount Merapi. Among them are Tlogolele Village of Selo District in Boyolali Regency and Balerante Village of Kemalang District in Klaten Regency of Central Java Province. The method used was cooperative inquiry as a form of action research. Data was collected through interview, observation, documentation analysis and focus group discussion (FGD). Informants were selected using purposive sampling. For each village, it has been chosen 20 informants consisting of economics and business group stakeholders at the village level. The results showed that currently sand mining becomes the source of income which is more convenient and practical for profit although as livelihood, it is unsustainable and non renewable. Meanwhile, community business after the eruption of Merapi has not been well developed and thus requires the implementation of empowerment programs and the continuous assistance. Community needs economics institution as a holding company to develop and promote all types of community business. This study has resulted in the development of a community empowerment model through the formation of cooperative as local economics strengthening.
\end{abstract}

Index Terms-Community, cooperative, empowerment, eruption.

\section{INTRODUCTION}

University as one of agents of change has duties and responsibilities to empower society. One of which is to participate in disaster and post-disaster relief. Since disaster management is essentially the duties and responsibilities of wider community and not only the duties and responsibilities of the government (Subiyantoro, 2010) [1], as part of wider community university is expected to develop science and technology of disaster management appropriate to the context of each region. This is in line with the National Disaster Management Plan 2010-2014 that put partnership with higher education as a strategy which can facilitate disaster management capacity enhancement of knowledge and technology at central and local level (BNPB, 2010) [2].

For that reason, in an effort to apply knowledge, concern and dedication for people affected by disaster, as researchers of Jenderal Soedirman University we conducted study in 2013 to identify, analyze and formulate community empowerment model in the villages most severely affected

Manuscript received August 9, 2014; revised October 13, 2014. This work was supported by the Directorate General of Higher Education, Ministry of Education and Culture of Republic of Indonesia.

The authors are with the Faculty of Social and Political Sciences, Jenderal Soedirman University, Indonesia (e-mail: unsoed.fisip@yahoo.com). by the eruption of Mount Merapi. According to data from the National Development Planning Agency (BAPPENAS) and the National Disaster Management Agency (BNPB) in 2011 [3] that eruption caused not only casualties and injuries but also resulted in great damage and loss in areas spread over two provinces and four regencies. Meanwhile, the most severely affected villages in those areas among others are Tlogolele Village of Selo District in Boyolali Regency, Jumoyo Village of Salam District in Magelang Regency and Balerante Village in Kemalang District of Klaten Regency in Central Java Province and Kepuharjo Village of Cangkringan District in Sleman Regency in Yogyakarta Province. The study showed community requires comprehensive empowerment activities which can ensure the sustainability of their business, needs cooperative as a business center to obtain capital, raw materials and network marketing access and should receive periodic training and disaster task force strengthening at the village level (Masrukin, et al., 2013) [4].

Then we have also conducted the second phase of study in 2014 which resulted in the development of community empowerment model through cooperative as economics institution strengthening that was devoted for the two study sites: Tlogolele Village of Selo District in Boyolali Regency and Balerante Village in Kemalang District of Klaten Regency in Central Java Province. The consideration of selection of the two locations were 1) those villages were worst affected by the eruption of Mount Merapi. 2) So far they have not got adequate empowerment programs such as training and mentoring. 3) the condition of road infrastructure was poor and their locations are far from the city. 4) the socio-economic situations of community were less developed than the other two locations.

Research on the model of community empowerment after the disaster is very important and strategic to accelerate the recovery of psychological and physical condition of community affected by improving their living and welfare. Empowerment provides an opportunity for individuals, groups or communities to control their own lives and shape their future according to their wishes (Shardlow in Adi, 2003) [5]. As according to Payne (1997: 226) [6] empowerment is "to help clients gain power of decision and action over their own lives by reducing the effect of social or personal blocks to exercising existing power, by increasing capacity and self confidence to use power and by transferring power from the environment to clients".

\section{RESEARCH Methode}

The method used in the preliminary study phase was case 
study. According to Blatter (2008: 68) [7] "a case study is a research approach in which one or a few instances of a phenomenon are studied in depth." Then in the second phase of study we used cooperative inquiry as a form of action research which required researchers interact and are deeply involved in the process and experience of participants and collaborate with them in every stage of research project (Vanderstoep and Johnston, 2009) [8].

Data collection was conducted by interviews, observation, documentation analysis and focus group discussions (FGD). Informants were selected using purposive sampling, so that the selection was based on the consideration of researchers that certain informants have extensive and deep experience about relevant issue and the ability to articulate it (Rolfe, 2009) [9]. Therefore, for each village it has been selected a number of 20 informants consisting of economics and business group stakeholders at the village level.

Data analysis techniques used was derived from Snape and Spencer (2003) [10] which has a process based on method of analysis constructing explanations from complexity, details and context of data and also identifying emerging categories and theories from the data found, not on the basis of a priori categories of ideas. It also noted the uniqueness of each case and cross-case analysis.

\section{RESUlTS AND ANALYSIS}

\section{A. The Process of Research}

Access opening to the research sites academically and methodologically is the first major requirement especially in the process of qualitative research because acceptance, closeness and harmony between researchers with participants will be critical in the implementation of interviews, FGD, observation and the activity of obtaining documentation. Closeness and acceptance of the informant will produce original, pure and natural data, including the documentation of the research process. Thus, in a qualitative study should be no distance between researchers and informants. Interwoven relationship between researchers and informants must be continuous, and uninterrupted (see Fig. 1-Fig. 2).

Based on the results of the access opening, interviews, and field observations, as well as the results of the first year study, it was agreed to implement the empowerment model by establishing cooperative as economics institution strengthening. The community empowerment model of the research process was as follows:

Researchers carried out action research method by conducting participatory and dialogic communication, meaning that the researcher acts more as a facilitator in exploring problems, needs, and aspirations of the community. Using cooperative inquiry researchers were more active in the group as a partner. Implementation of FGD was performed prior to the implementation of the model. Therefore, the research team conducted introduction, explanation and dissemination of the objectives, mechanisms and results achieved in the first year of study in the form of establishing cooperative as empowerment model. FGD resulted in the development of empowerment model in the form of training on managerial administration, finance and membership as well as training on new business development, partnerships and marketing cooperative product. The process of determining the implementation of community empowerment model through the formation of cooperatives as economics institution strengthening is as follows:

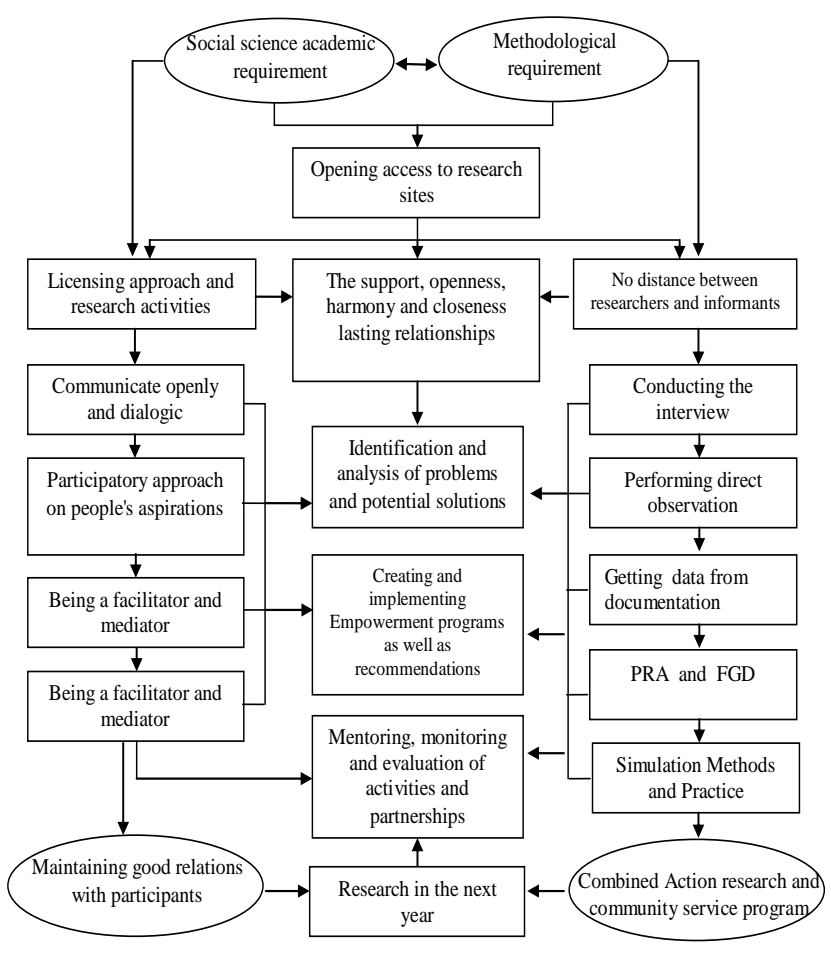

Fig. 1. Modeling of community empowerment research process.

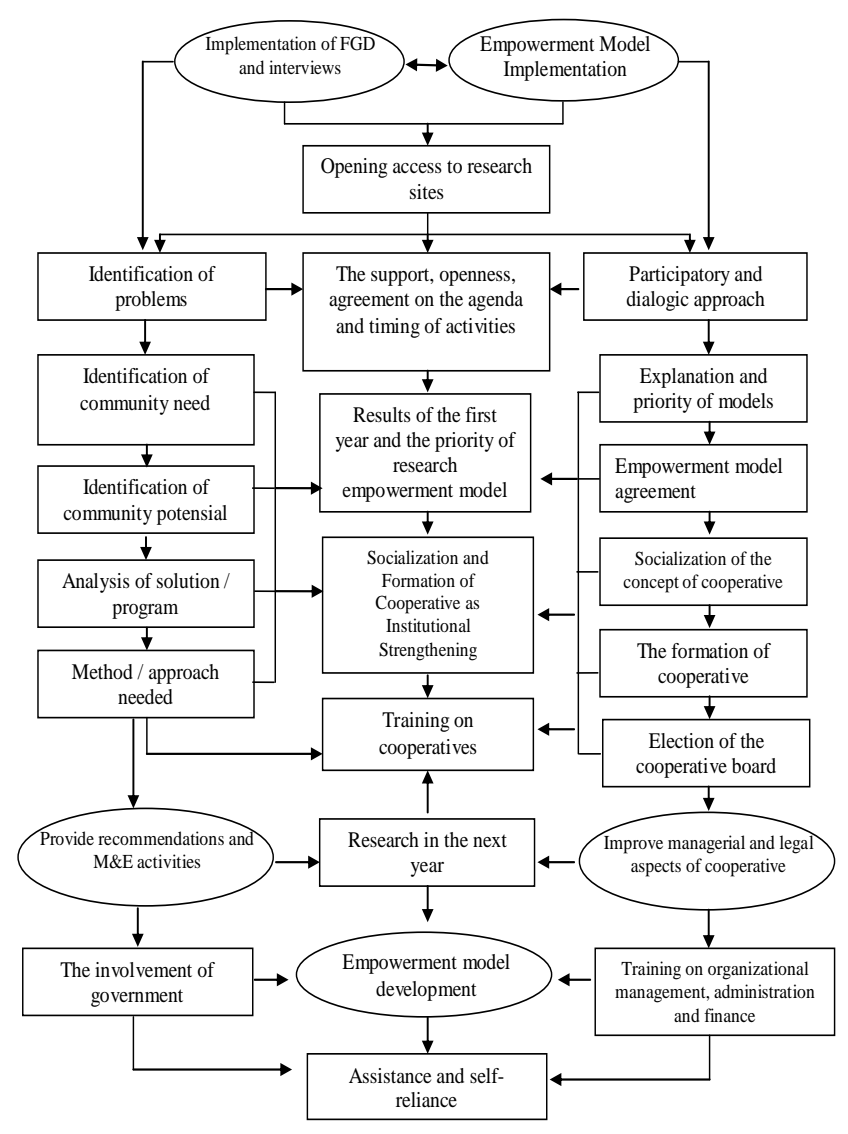

Fig. 2. FGD process modeling and the implementation of employment model. 


\section{B. The Development of Community Empowerment Model}

The first thing that have to be done to meet the economics need of people affected by eruption of Merapi, among others, is to revive the old businesses that do not require physical improvements, trading activity in traditional markets, the provision of seeds, provision of capital or soft loans, means of production, animal feed, assisting small and medium enterprises in marketing their products, creating new livelihood and or utilizing existing material (Andrayani, 2011) [11] (see Fig. 3).

In line with this our study in the first year proposed some recommendations for the village of Tlogolele as follows: 1) Empowerment of village disaster preparedness group. It is also recommended by BPBD of Central Java when the research team conducted hearings in 2013 to discuss and recommend research findings. 2) Empowerment of dairy farms that integrate with organic vegetable farming. 3) Empowerment of community through the formation of cooperatives as a holding company. Likewise in the village of Balerante, the first study resulted in several alternative models of empowerment as follows: 1) Innovation on the technology of clove oil production. 2) The production of cattle feed processing. 3) Improvement of processed foods production. 4) Establishment of cooperatives as parent economics enterprises.

The formation of cooperative then was chosen as a model of community empowerment for institutional economics strengthening and to improve the welfare of the villagers. This was due to the following considerations:

1) Currently sand mining is the source of income for the villagers which is more convenient and practical for profit. So that people are turning to the profession or business type of sand mining. However, in terms of livelihood, it is unsustainable and non renewable as well. There must be an alternative economic activities to reduce community dependence on sand mining

2) Other possible empowerment solutions require very comprehensive research activities involving multi-disciplinary teams including scientists from agriculture, animal husbandry and need support from relevant agencies. Then, it also requires numerous research funding.

3) The community business after the eruption of Mount Merapi has not been well developed and thus require the implementation of empowerment programs and the continuous assistance

4) The choice and request of people in the village of Tlogolele and Balerante. Community needs economics institution as a holding company to develop and promote all types of community business.

5) The establishment of cooperatives is very important and strategic in strengthening economic institutions and increased well-being because all economic business institutions in the village will be integrated into cooperative in terms of capital, business licenses, lending, marketing and business assistance

6) Cooperative is very easy in the process of its formation and development because it can accommodate all types of community business. In addition, membership and dues are simple and lightweight. Then the local government has a cooperative service affair which can be asked to help the sustainability of empowerment.
In these two locations, cooperative have not been formed and was still in the planning stages of the community. So that the implementation of the empowerment model through cooperatives in the second year of research carried out with the following activities: 1) Dissemination of the concept, purpose and benefits of cooperative. It was delivered through discussion to open their paradigm about the importance of joint efforts in a cooperative and the urgency of participation of all parties together for the common good. 2) Capacity building or training on organizational management, administration and finance of the cooperatives. It was intended to provide the knowledge, skill and understanding that cooperatives should be managed professionally 3) The establishment of cooperative board with officials election simulation, ranging from the chairman and his staff that will further become pioneering force of cooperative. The result was the formation of cooperative board of the village, as well as the agreement on cooperative's name. 4) Obtaining legal status to improve networking of cooperative with formal and authorized institution and conducting study visit to an advanced and successful cooperative. We have met related local government agencies and they were willing to facilitate the establishment of the cooperative as a legal entity. However, we have not facilitated them to do study visit. 5) Building synergy with local development actors. Successful empowerment programs needs coordination and cooperation between universities, government, NGOs, banks, and local community itself.

Therefore, the development of community empowerment model by economics strengthening through the establishment of cooperative institutions are as follows

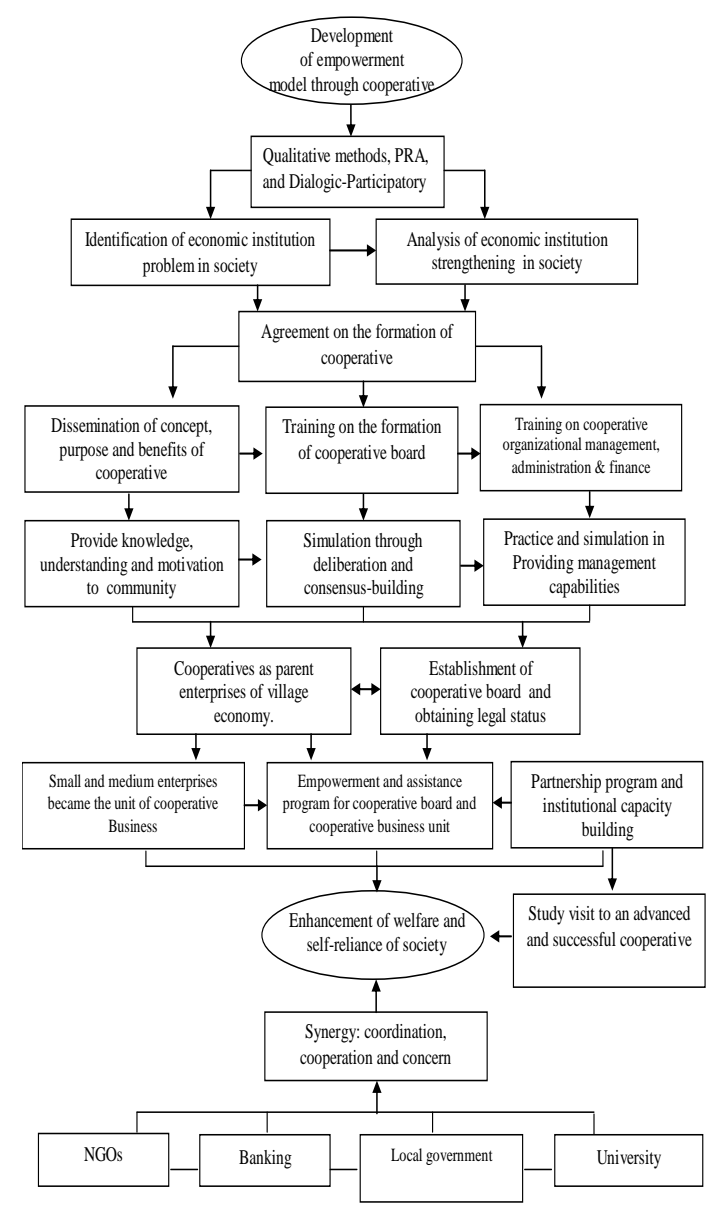

Fig. 3. Community empowerment model through cooperative. 


\section{CONCLUSION}

The establishment of cooperatives is very important and strategic in strengthening local economic institutions and increased well-being. Because, all the economic business institutions in the village will be integrated into cooperative in terms of capital, business licenses, lending, marketing and business assistance. Furthermore, cooperative is very easy in the process of its formation and development because it can accommodate all types of business community. In addition, membership and dues are uncomplicated and lightweight. Then the local government has agency which can help to facilitate the sustainability of cooperative.

The community empowerment model through cooperative for the villages most severely affected by eruption of Merapi has been done through an integrated strategy of empowerment ranging from the stage of disseminating conscience on the importance of cooperative to an effort of building synergy with other local development actors. In addition, capacity building, cooperative board establishment and obtaining legal status were held in between. Dissemination was intended to stimulate the sense of urgency about cooperative and cultivate understanding that cooperatives require participation of all parties simultaneously for their success. Capacity building was held to make members of cooperatives get prepared to work in professional manner. The establishment of cooperative board with official election simulation was conducted to breed the pioneers of cooperative. Getting legal status would give benefit for official networking enhancement. Finally, to conduct successful cooperative based empowerment the synergy, coordination and cooperation between university, local government, NGO, bank, and local community itself are strongly needed.

Last but not least, it is very important to conduct further research to implement a comprehensive model of community empowerment in agriculture, livestock and small enterprises. This also requires very comprehensive research activities involving multidisciplinary teams including scientists from agriculture, animal husbandry and related agencies.

\section{REFERENCES}

[1] I. Subiyantoro, "Upaya mengantisipasi bencana melalui kekuatan berbasis masyarakat," Jurnal Dialog Penanggulangan Bencana, vol. 1 , no. 2, pp. 9-16, 2010.

[2] BNPB, Rencana Nasional Penanggulangan Bencana 2010 - 2014, Jakarta: BNPB, 2010

[3] BAPPENAS and BNPB, Rencana Aksi Rehabilitasi dan Rekonstruksi Wilayah Pascabencana Erupsi Gunung Merapi di Provinsi D.I. Yogyakarta dan Provinsi Jawa Tengah Tahun 2011-2013, Jakarta: BAPPENAS and BNPB, 2011.

[4] M. T. Sugito, B. Suswanto, and A. Sabiq, "Model pemberdayaan masyarakat pasca erupsi gunung merapi di jawa tengah dan yogyakarta," Jurnal Komunitas, vol. 2, no. 5, pp. 172-184, 2013

[5] I. R. Adi, Pengembangan Masyarakat Dan Intervensi Komunikasi (Pengantar pada Pemikiran dan Pendekatan Praktis), Jakarta: Fakultas Ekonomi Universitas Indonesia, 2003.

[6] M. Payne, Modern Social Work Theory, Second Edition, London: McMillan Press Ltd, 1997

[7] J. K. Blatter, "Case study," The Sage Encyclopaedia of Qualitative Research Methods, Los Angeles, London, New Delhi, Singapore : Sage Publication, vol. 1-2, 2008.
[8] S. W. Vanderstoep and D. D. Johnston, Research Methodes for Every Day: Blending Qualitative and Quantitative Approaches, San Francisco: Jossey-Bass, 2009.

[9] G. Rolfe, "Essentialism," The Sage of Encyclopedia of Qualitative Research Methods, Los Angeles, London, New Delhi, Singapore: Sage Publication, vol. 1-2, 2009.

[10] D. Snape and L. Spencer, "The Foundations of qualitative research," Qualitative Research Practice: A Guide for Social Science Student and Researchers, London, Thousand Oaks, New Delhi : Sage Publication, 2003

[11] T. T. Andrayani, "Dana sumbangan masyarakat untuk pembangunan ekonomi pascabencana merapi," Jurnal Penanggulangan Bencana, vol. 2, no. 1, pp. 41-49, 2011.

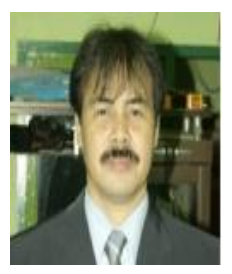

Masrukin is a lecturer in the Department of Sociology, Faculty of Social and Political Sciences, Jenderal Soedirman University. He got his doctorate from Padjajaran University, Bandung, Indonesia in the field of sociology in 2006. He currently serves as a vice dean of academics affairs at that faculty. He specializes in rural sociology and community empowerment.

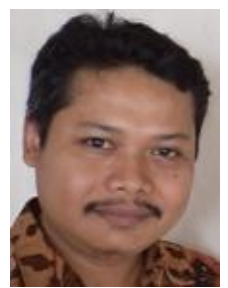

Ahmad Sabiq is a lecturer in the Department of Political Sciences, Faculty of Social and Political Sciences, Jenderal Soedirman University. He obtained his MA from Institute of Social Studies, The Hague in Local and Regional Development in 2005. He currently serves as the head of cooperation affairs section at that faculty. He specializes in local politics, social movement and community empowerment.

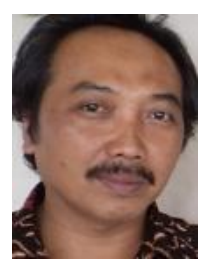

Toto Sugito is a lecturer in the Department of Communication, Faculty of Social and Political Sciences, Jenderal Soedirman University. He obtained his doctorate from Padjajaran University, Bandung, Indonesia in the field of Communication in 2010 . He currently serves as the head of communication department at that faculty. He specializes in rural sociologi and community empowerment.

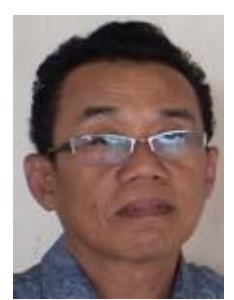

Bambang Suswanto is a lecturer in the Department of Political Sciences, Faculty of Social and Political Sciences, Jenderal Soedirman University. He got his post graduate degree from Gadjah Mada University, Yogyakarta, Indonesia in national resilience in 2000.

$\mathrm{He}$ specializes in conflict and consensus and community empowerment.

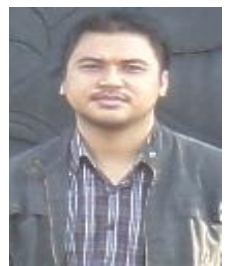

Adhi Iman Sulaiman is a lecturer in the Department of Political Sciences, Faculty of Social and Political Sciences, Jenderal Soedirman University. He obtained his post graduate degree from Padjadjaran University, Bandung, Indonesia in the field of communication in 2008. He specializes in communication, development and community empowerment. 